\title{
Clinical, ultrasonographic and histological findings in varicose vein surgery
}

\author{
Moacir de Mello Porciunculla \\ Dafne Braga Diamante Leiderman² \\ Rodrigo Altenfeder ${ }^{\mathbf{1}}$ \\ Celina Siqueira Barbosa Pereira ${ }^{1}$ \\ Alexandre Fioranelli ${ }^{1}$ \\ Nelson Wolosker ${ }^{2,3}$ \\ Valter Castelli Junior ${ }^{\mathbf{1}}$
}

\begin{abstract}
1. Medical Science Faculty of the Santa Casa of São Paulo, São Paulo/SP, Brasil 2. Hospital Israelita Albert Einstein, São Paulo/SP, Brasil 3. Hospital das Clínicas of the Faculty of Medicine of the University of São Paulo, São Paulo/SP, Brasil
\end{abstract}

\section{SUMMARY}

OBJECTIVE: This study aims to correlate the demographic data, different clinical degrees of chronic venous insufficiency (CEAP), ultrasound findings of saphenofemoral junction (SFJ) reflux, and anatomopathological findings of the proximal segment of the great saphenous vein (GSV) extracted from patients with primary chronic venous insufficiency (CVI) submitted to stripping of the great saphenous vein for the treatment of lower limb varicose.

METHOD: This is a prospective study of 84 patients (110 limbs) who were submitted to the stripping of the great saphenous vein for the treatment of varicose veins of the lower limbs, who were evaluated for CEAP clinical classification, the presence of reflux at the SFJ with Doppler ultrasonography, and histopathological changes. We study the relationship between the histopathological findings of the proximal GSV withdrawal of patients with CVI with a normal GSV control group from cadavers.

RESULTS: The mean age of the patients was higher in the advanced CEAPS categories when comparing C2 (46,1 years) with C4 (55,7 years) and C5-6(66 years), as well as C3 patients (50,6 years) with C5-6 patients. The normal GSV wall thickness (mean 839,7 micrometers) was significantly lower than in the saphenous varicose vein (mean 1609,7 micrometers). The correlational analysis of reflux in SFJ with clinical classification or histopathological finding did not show statistically significant findings.

CONCLUSIONS: The greater the age, the greater the clinical severity of the patients. The GSV wall is thicker in patients with lower limb varicose veins, but those histopathological changes are not correlated with the disease's clinical severity or reflux in the SFJ on a Doppler ultrasound.

KEYWORDS: Varicose veins. Ultrasonography. Histology.

\section{INTRODUCTION}

Amongst chronic vascular diseases, the chronic venous insufficiency (CVI) of the lower limbs (LLS) is the most prevalent. ${ }^{1}$ In Brazil, the prevalence ranges from $35 \%$ to $50 \%$ of the adult population. ${ }^{2,3}$ As for socioeconomic impact, according to the Ministry of Health, CVI occupies the 14th position among the 50 top diseases to cause temporary or permanent leave from work, resulting in the payment of benefits to those ensured by the Brazilian social security system and still of working age. ${ }^{4}$

Histological performed on varicose veins have demonstrated contradictory findings of the structural changes in the smooth muscle of the venous wall. ${ }^{5}$ Some researchers have reported an increase in that 
muscle's quantity or activity ${ }^{6}$, while others have observed reduced amounts of smooth muscle associated to the replacement of connective tissue., ${ }^{7}$ It has also been suggested that the segregation of muscle cells by fibrous infiltration could interfere on the performance of those cells as a whole, resulting in alterations of the venous wall and, consequently, abnormal dilation. ${ }^{9}$ However, other studies were not able to demonstrate any differences between varicose veins and normal veins regarding muscle content of the venous wall. ${ }^{8}$

In the Brazilian national literature, there are no studies on the correlation of histopathological findings relating to the trunk of the great saphenous vein (GSV) with anamnesis of physical examination data. There are also no sufficiently conclusive reports regarding the thickness alterations of the GSV wall on lighter or more advanced classes of the CEAP clinical classification to explain whether there is any difference in the response of the venous wall thickness in the comparison amongst patients who have undergone surgery multiple times.

\section{OBJECTIVE}

The objective of this study is to correlate demographic data and the different clinical levels of chronic venous insufficiency (CEAP) with ultrasound findings of reflux in the saphenofemoral junction and anatomopathological findings of the proximal segment of the great saphenous vein extracted from patients with chronic venous insufficiency who underwent stripping of the great saphenous vein to correct lower limb varicose.

\section{METHODOLOGY}

A total of 84 consecutive patients were prospectively studied with a mean age of $51.2 \pm 11.9$ years, ranging from 21 to 74 years, out of which $63.6 \%$ were females, with CVI who underwent surgical treatment for varicose of 110 lower limbs and total unilateral stripping of the greater saphenous vein (58 patients) or bilateral (26 patients), over a period of three years in the Santa Casa de Misericórdia of São Paulo. The study was approved by the Research Ethics Committee (CEP) (235/06).

We used the CEAP clinical classification to standardize the physical assessment of patients. The clinical classification (C) is described below:

CO: No visible or palpable signs of venous disease
C1: Telangiectasies and reticular veins

C2: Varicose veins

C3: Edema

C4a: Brown pigmentation (ochre dermatitis) and/ or eczema

C4b: Lipodermatosclerosis or athrophie blanche

C5: Healed venous ulcer

C6: Active venous ulcer

The inclusion criteria were: the presence of primary symptomatic varicose veins; absence of obstructions of the deep venous system (DVT); limbs with GSV at thigh level with reflux in the Doppler ultrasound (reflux criteria used $>0.5$ seconds) and with CEAP clinical categories $\mathrm{C} 2$ to $\mathrm{C} 6$.

All information was collected using an specific form that included anamnesis, the clinical examination using the CEAP categories, ultrasound data (reflux of the great saphenous vein with or without saphenofemoral junction reflux), surgical data, and the anatomopathological study of the proximal portion of the great saphenous vein arch removed during surgery, the segment between the surgical ligation of the saphenous vein at the saphenofemoral junction and a second segment $1 \mathrm{~cm}$ below it, where the GSV is attached to the vein stripper.

The venous segments were removed for analysis and put in a 10\% formalin solution for no longer than 48 hours. Cross-sections were made, which were included in the paraffin and stained with hematoxylin and eosin and the Masson's trichrome in order to measure the thickness of the vessel, the only parameter selected for histopathological assessment in this study. The pieces were analyzed in an optical microscope with a magnification of 50x, and the images captured with an attached camera to digitally measure the greater thickness of the vessel, from the tunica intima to the adventitia.

For the anatomopathological analysis, a control group was created in which normal great saphenous veins were removed from five corpses with the same mean age, death unrelated to vascular diseases, and absence of clinical signs of reports of chronic venous disease and upon consent of family members. A total of 10 samples of the great saphenous vein were collected with the same procedure conducted for in vivo samples. The samples were submitted to the same preparation procedures and anatomopathological analysis, and the maximum thickness of the venous wall of the great saphenous vein found was consid- 
ered the control. Bearing in mind that the thickness is not the uniform around the vessel, we used the biggest measurement for the analysis.

We analyzed and correlated demographic data, clinical findings with the CEAP classification, the presence of pathological reflux of the SFJ detected by color Doppler ultrasound, and histological changes in the thickness of the GSV arch wall upon optical microscopy. Lastly, we compared the average of the greatest GSV wall thickness at the arch in patients with CVI who underwent varicose surgical treatment with the healthy great saphenous vein obtained from cadavers (control group).

The statistical study considered data expressed in frequencies and means, averages and standard deviations. The chi-square test was applied for frequency comparison; the Student's t-test was used to compare means and standard deviations; and the Pearson's $r$ coefficient for correlations between dependent and independent variables. To analyze the null hypothesis, a probability of $95 \%(\mathrm{p}<0.05)$ was adopted.

\section{RESULTS}

Analyzing the relationship between the different CEAP clinical categories and patient gender, we found that most cases $\left(x^{2}=79.3089 ; p<0.0001\right)$ were in the CEAP category C3 (60.0\%) for both genders. The relationship between CEAP classification and patient gender and age is presented in Table 1.

The patient age distribution was similar in different CEAP clinical classifications. Regarding the different clinical categories and patient age, we observed that the older the patient, the greater the severity of the varicose veins $(r=0.3268 ; p<0.05)$. We found a statistical difference when comparing CEAP $\mathrm{C} 2$ patients with CEAP categories $\mathrm{C} 4(\mathrm{p}=0.0035)$ and C5-6 (0.027), as well as when comparing CEAP C3 patients with C5-6 ( $\mathrm{p}=0.0374)$.

Reflux in the SFJ was found in $81.8 \%$ of GSVs, with reflux at the thigh. No statistical difference was found in the analysis comparing the average age of patients with reflux (51.7 years) and without reflux (49 years) at the arch of the GSV, with $p=0.3621$. The relationship between the CEAP clinical classification and the presence of reflux in the SFJ is shown in Table 2.

No relationship was found between CEAP clinical categories and the presence of reflux in the SFJ (Table 3). Most cases that presented reflux in the SFJ were in category 3 , with a higher frequency of that clinical category in the general sample.

The thickness of the normal GSV (ranging from 401-1.175, mean of 839.7+-243 micrometers) was significantly lower $(p<0.0001)$ than in the GSV varicose

TABLE 1 - RELATIONSHIP BETWEEN CEAP CLINICAL CATEGORIES AND PATIENT GENDER AND AGE DISTRIBUTION FOR EACH CATEGORY

\begin{tabular}{l|l|l|l|l|l|l|l|l}
\multirow{2}{*}{$\begin{array}{l}\text { CEAP } \\
(\mathrm{C})\end{array}$} & \multicolumn{2}{l}{ Male $(\mathrm{n}=40)$} & \multicolumn{3}{l|}{ Female $(\mathrm{n}=\mathbf{7 0})$} & \multicolumn{2}{l|}{ Total } & \multicolumn{2}{l}{ Age } \\
\cline { 2 - 11 } & $\mathrm{n}$ & $\%$ & $\mathrm{n}$ & $\%$ & $\mathrm{n}$ & $\%$ & \multicolumn{2}{l}{ Mean (Min-Max) } \\
\hline 2 & 7 & 17.5 & 13 & 18.6 & 20 & 18.2 & $46.1(31-71)$ & $\mathrm{X}^{2}=2.9728$ \\
\hline 3 & 21 & 52.5 & 45 & 64.3 & 66 & 60.0 & $50.6(21-74)$ & $\mathrm{p}=0.3958$ \\
\hline 4 & 11 & 27.5 & 10 & 14.3 & 21 & 19.1 & $55.7(37-71)$ & \\
\hline 5 & 0 & - & 2 & 2.8 & 2 & 1.8 & $66.0(62-74)$ & \\
\hline 6 & 1 & 2.5 & 0 & - & 1 & 0.9 & & \\
\hline
\end{tabular}

TABLE 2 - RELATIONSHIP BETWEEN CEAP CLINICAL CATEGORIES AND THE PRESENCE OF REFLUX IN THE SFJ

\begin{tabular}{l|l|l|l|l|l|l|l}
$\begin{array}{l}\text { CEAP } \\
\text { Category } \\
(C)\end{array}$ & \multicolumn{3}{|l|}{ Present $(\mathrm{n}=88)$} & \multicolumn{2}{l|}{$\begin{array}{l}\text { Reflux } \\
\text { Absent }(\mathrm{n}=20)\end{array}$} & $\begin{array}{l}\text { Total } \\
(\mathrm{n}=110)\end{array}$ & Statistics \\
\cline { 2 - 9 } & $\mathrm{n}$ & $\%$ & $\mathrm{n}$ & $\%$ & $\mathrm{n}$ & $\%$ & \\
\hline 2 & 13 & 14.5 & $7^{\wedge}$ & 35 & 20 & 18.2 & \\
\hline 3 & 58 & 64.4 & 8 & 40 & 66 & 60.0 & \\
\hline 4 & 171 & 18.9 & 4 & 20 & 21 & 19.1 & \\
\hline 5 & 1 & 1.1 & 1 & 5 & 2 & 1.8 & \\
\hline 6 & 1 & 1.1 & 0 & - & 1 & 0.9 & $x^{2}=6.635 ; p=0.1564$ \\
\hline
\end{tabular}


veins (ranging from 802-2.663, mean of 1,609+,7376). There was no relationship between gender and age distribution and GSV thickness.

The analysis of the varicose GSV thickness with the CEAP classification, the presence of reflux at the GSV arch, uni- or bilateral involvement, and family history are shown in Table 3.

The relationship was demonstrated between thickness and the CEAP classification, the presence of reflux at the GSV arch, and uni- or bilateral involvement. We found that $95.5 \%$ of patients reported a family history of CVI, and in $32.7 \%$ of cases, there was a previous family history of LLS surgery. Such influence has not been proven during the statistical analysis of the cases.

The images of the lowest, average, and highest values recorded during the measuring of GSV wall thickness in the control and study groups are presented in Figure 1.

\section{DISCUSSION}

Our study group consists of patients with symptomatic varicose veins and GSV insufficiency at the thigh who sought help at a large public hospital in the city of São Paulo and, after the recommendation of conventional surgery, were consecutively included in the study. These patients are mostly aged between $30-50$ years $(48.8 \%)$, with a greater proportion of males (63.6\% females and $36.4 \%$ males) than in other published studies, 3 to 6 women for 1 man. ${ }^{1,10,11}$ This discrepancy with the literature is not explained by

TABLE 3 - RELATIONSHIP BETWEEN THE VARICOSE GSV THICKNESS AND THE CEAP CLASSIFICATION, THE PRESENCE OF REFLUX AT THE GSV ARCH, FAMILY HISTORY, AND UNI- OR BILATERAL INVOLVEMENT

\begin{tabular}{|c|c|c|c|c|}
\hline \multicolumn{2}{|l|}{ Variables } & \multirow{2}{*}{$\begin{array}{l}\text { Thickest } \\
\text { Average }\end{array}$} & \multirow{2}{*}{$\begin{array}{l}\text { Measurement } \\
\text { Standard } \\
\text { deviation } \\
351 \\
384 \\
344 \\
718\end{array}$} & \multirow{2}{*}{$\begin{array}{l}\text { Statistics } \\
p>0.05\end{array}$} \\
\hline CEAP & $\begin{array}{l}2 \\
3 \\
4 \\
5 \text { and } 6\end{array}$ & & & \\
\hline Altered reflux & $\begin{array}{l}\text { Present } \\
\text { Absent }\end{array}$ & $\begin{array}{l}1,629.6 \\
1,520.2\end{array}$ & $\begin{array}{l}385.5 \\
324.3\end{array}$ & $p=0.2411$ \\
\hline Family history & $\begin{array}{l}\text { Present } \\
\text { Absent }\end{array}$ & $\begin{array}{l}1,618 \\
1,434.4\end{array}$ & $\begin{array}{l}381 \\
202\end{array}$ & $p=0.2882$ \\
\hline $\begin{array}{l}\text { Family } \\
\text { members who } \\
\text { underwent } \\
\text { surgery }\end{array}$ & $\begin{array}{l}\text { Present } \\
\text { Absent }\end{array}$ & $\begin{array}{l}1,601.4 \\
1,613.7\end{array}$ & $\begin{array}{l}369 \\
382\end{array}$ & $p=0.8734$ \\
\hline $\begin{array}{l}\text { Type of involve- } \\
\text { ment }\end{array}$ & $\begin{array}{l}\text { Unilateral } \\
\text { Bilateral }\end{array}$ & $\begin{array}{l}1,661.2 \\
1,552.2\end{array}$ & $\begin{array}{l}379.4 \\
367.5\end{array}$ & $p=0.1295$ \\
\hline
\end{tabular}

the CVI severity in our study, since, despite previously published works having included less advanced categories of the disease with a bigger aesthetic problem, the advanced clinical categories (C4, C5, and C6) have the same distribution for both genders. Although the evidence of genetic predisposition for varicose veins is still not highly conclusive, a family history of CVI was reported by $95.5 \%$ of the patients in this study.

The CEAP clinical classification for assessing the level of patient compromise due to chronic venous disease of the lower limbs was elaborated in the American Venous Forum held in 1994, and its adoption as a universal language was helpful to a more homogeneous understanding of the venous disease, allowing for the use of such classification in scientific studies.12 In this study, 21.8\% of members had advanced CVI, categorized as CEAP C\$, 5 , or 6 , in which there is a greater technical difficulty in surgery and worse outcomes due to lipodermatofibrosis, eczema, and active or healed ulcers, in addition to higher recurrence rates. ${ }^{13,14}$ In this study, all patients were submitted to conventional surgery, during which samples of the GSV arch segment were collected. The effectiveness of conventional varicose surgery and its low recurrence rates are undeniable, ${ }^{15,16}$ which makes this technique the gold standard for varicose vein treatment. Despite the increase in the use of modern techniques of venous thermal ablation and the fact that its effectiveness is comparable to conventional surgery, Mendes et al. ${ }^{17}$ demonstrated, in a randomized study, that if patients are not told the technique used, they cannot differentiate the conventional surgery from the radiofrequency ablation.

We found a clear progression of the clinical classification of the disease with increasing age when comparing early clinical classifications C2 (average age of 46.1 years) and C3 with the advanced classifications C4 and C5-6, with a statistically significant difference despite the lower number of C5-6 patients (three patients, average age of 66 years). The low number of C5-6 patients is the result of the inclusion of consecutive patients who met the research inclusion criteria associated with a lower frequency of the advanced classifications of the disease in the general population. The clinical deterioration with increasing age reveals the natural history of the disease, illustrating that the complications and severity of CVI increase over the years in patients with no definitive treat- 
FIGURE 1: (A) Lowest value recorded in the control group: 401 micrometers; (b) Smaller value recorded in the study group: 801 micrometers; (c) Value closest to the average value of the control group: 866 micrometers; (d) Value closest to the average value of the study group: 1,606 micrometers; (e) Highest value recorded in the control group: 1,175 micrometers; (f) Highest value recorded in the study group: 2,663 micrometers.
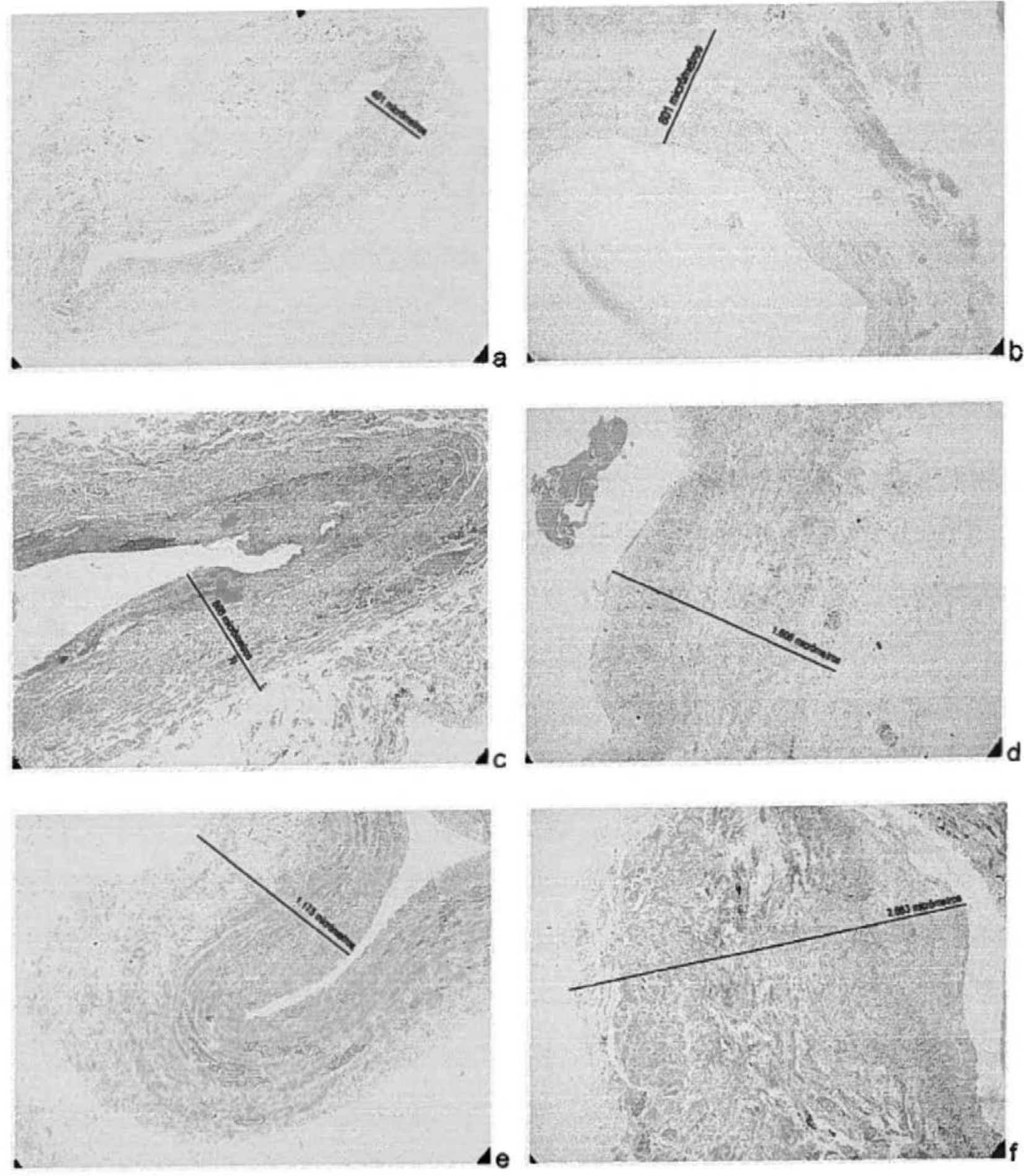

ment, and that there may be a lack of information among the population regarding the evolution of the chronic venous disease and its complications when there is no early treatment, evidencing the need for awareness campaigns.
In our study, we included patients with GSV reflux in the thigh, and reflux in the saphenofemoral junction was the ultrasound factor studied, since one of the sources of proximal GSV reflux, an important cause for varicose recurrence, direct- 
ly interferes in the surgical approach and the postoperative results. The abnormal reflux in the saphenofemoral junction is considered the cause for $60 \%$ to $80 \%$ of all primary varicose vein cases.18 In line with some other studies,18,19 we found altered reflux in the saphenofemoral junction in $81.8 \%$ of the limbs analyzed with GSV reflux in the thigh. Seidel et al. ${ }^{10}$ studied the association between CVI symptoms, visible varicose veins, and GSV reflux, grouping patients in three different groups (asymptomatic with varicose veins, symptomatic with no varicose veins, and symptomatic with varicose veins) and concluded that GSV reflux was more frequent in symptomatic patients with visible varicose veins, however they did not study the relevance of SFJ insufficiency on symptoms and on the level of varicose veins visible during the physical examination. Even though the presence of altered SFJ reflux is a relevant parameter for surgical recommendation ${ }^{20}$ and predictor of $\mathrm{CVI},{ }^{19}$ the presence of such reflux presented no correlation with the clinical classification of CVI (CEAP) in this study, i.e. Patients with saphenofemoral junction reflux did not present a more advanced clinical stage than patients with SFJ and no pathological reflux. Yamaki et al. ${ }^{21}$ also did not find an association between the presence of superficial venous reflux or isolated perforator insufficiency and the early (CEAP C1-3) or advanced (CEAP C4 to 6) CVI clinical categories. However, the maximum reflux speed and maximum volume of reflux in the great saphenous vein, saphenofemoral and saphenopopliteal junctions, and deep venous system are higher in patients with advanced CEAP.

Even though alterations in the composition of the venous wall are considered the basic dysfunction for all $\mathrm{CVI}^{8}$ and are related to GSV insufficiency, ${ }^{10}$ our study did not show any relationship between an increased thickness of the GSV wall and the presence of SFJ reflux.

Amongst possible structural alterations in the varicose GSV, the focus of our study was the thickness of the GSV wall in SFJ. Santos Ferreira ${ }^{22,23}$ found the thickening of the venous walls, especially in distal positions and in the tunica intima, to be the main and most frequent histological alteration in varicose veins. Silveira ${ }^{24}$ found thicker walls in varicose veins than in normal veins in all three tunicas. In our study we also found thicker walls in varicose veins than in normal veins obtained from cadavers with no history of venous disease, but found no correlation between such increased thickness and clinical and ultrasound data, thus confirming the findings of Santos Ferreira and the observations of Garrido et al. ${ }^{22,23}$

\section{CONCLUSIONS}

The findings in this study confirm that the clinical classification of CVI is more severe with increased patient age. However, the thickness of the arch of the great saphenous vein is bigger in patients with varicose veins of the lower limbs, and these alterations do not correlate to the clinical classification of the disease or the presence of pathological reflux in the SFJ identified by Doppler ultrasound.

\section{RESUMO}

OBJETIVO: Este estudo tem como objetivo correlacionar os dados demográficos, os diferentes graus clínicos da insuficiência venosa crônica (Ceap), com achados ultrassonográficos de refluxo da junção safenofemoral (JSF) e os achados anatomopatológicos do segmento proximal da veia safena magna (VSM) extraído de pacientes com insuficiência venosa crônica (IVC) primária submetidos à safenectomia magna para correção de varizes dos membros inferiores.

MÉTODO: Estudo prospectivo de 84 pacientes e 110 membros submetidos à safenectomia magna para o tratamento de varizes de membros inferiores, correlacionando a sua classificação clínica Ceap, presença de refluxo na JSF ao ultrassom Doppler e alterações histopatológicas. Comparamos ainda os achados histopatológicos da VSM proximal retirada dos pacientes com IVC com grupo controle de VSM normal retirada de cadáveres.

RESULTADOS: Média de idade dos pacientes foi maior nos Ceaps avançados quando comparado Ceap C2 (46,1 anos) com C4 (55,7 anos) e C5-6 (66 anos), e pacientes C3 (50,6 anos) com C5-6. A espessura da parede da VSM normal (média de 839,7 micrômetros) foi significativamente menor do que das VSM varicosas (média de 1.609,7 micrômetros). As análises de correlação da presença do refluxo em JSF com a classificação clínica ou achado histopatológico não demostraram ser estatisticamente significativas.

CONCLUSÕES: Quanto maior a idade, mais avançada é a classificação clínica da IVC dos pacientes. A espessura da parede da crossa da VSM é maior nos pacientes com IVC e essas alterações não se correlacionam com a classificação clínica da doença ou com a presença de refluxo na JSF ao ultrassom Doppler.

PALAVRAS-CHAVE: Varizes. Ultrassonografia. Histologia. 


\section{REFERENCES}

1. Hobson J. Venous insufficiency at work. Angiology. 1997;48(7):577-82.

2. Cabral ALS. Insuficiência venosa crônica de membros inferiores: prevalência, sintomas e marcadores preditivos [Tese de doutorado]. São Paulo: Universidade Federal de São Paulo, Escola Paulista de Medicina; 2000. p.140.

3. Maffei FH, Magaldi C, Pinho SZ, Lastoria S, Pinho W, Yoshida WB, et al. Varicose veins and chronic venous insufficiency in Brazil: prevalence among 1755 inhabitants of a country town. Int J Epidemiol. 1986;15(2):210-

4. Mallick R, Lal BK, Daugherty C. Relationship between patient-reported symptoms, limitations in daily activities, and psychological impact in varicose veins. J Vasc Surg Venous Lymphat Disord. 2017;5(2):224-37.

5. Abramson DI. Diseases of the veins: pathology, diagnosis and treatment. IAMA. 1988;260(24):3680.

6. Obitsu Y, Ishimaru S, Furukawa K, Yoshihama I. Histopathological studies of the valves of varicose veins. Phlebology. 1990;5(4):245-54.

7. Rose SS, Ahmed A. Some thoughts on the aetiology of varicose veins. I Cardiovasc Surg (Torino). 1986;27(5):534-43.

8. Jacobs BN, Andraska EA, Obi AT, Wakefield TW. Pathophysiology of varicose veins. J Vasc Surg Venous Lymphat Disord. 2017;5(3):460-7.

9. Wali MA, Dewan M, Eid RA. Histopathological changes in the wall of varicose veins. Int Angiol. 2003;22(2):188-93.

10. Seidel AC, Campos MB, Campos RB, Harada DS, Rossi RM, Cavalari Junior $P$, et al. Associação entre sintomas, veias varicosas e refluxo na veia safena magna ao eco-Doppler. J Vasc Bras. 2017;16(1):4-10.

11. Seidel AC, Mangolim AS, Rossetti LP, Gomes JR, Miranda Jr F. Prevalência de insuficiência venosa superficial dos membros inferiores em pacientes obesos e não obesos. J Vasc Bras. 2011;10(2):124-30.

12. Venous Forum Annual Meeting, Royal Society of Medicine, London, 14 October 1994. Phlebology. 2016;10(2):79-85.

13. Kokkosis AA, Schanzer H. Anatomical and clinical factors favoring the performance of saphenous ablation and microphlebectomy or sclerotherapy as a single-stage procedure. Phlebology. 2015;30(9):627-31.

14. van der Velden SK, Pichot $O$, van den Bos RR, Nijsten TE, De Maeseneer
MG. Management strategies for patients with varicose veins (C2-C6): results of a worldwide survey. Eur J Vasc Endovasc Surg. 2015;49(2):213-20.

15. Lurie F, Creton D, Eklof B, Kabnick LS, Kistner RL, Pichot O, et al. Prospective randomized study of endovenous radiofrequency obliteration (closure procedure) versus ligation and stripping in a selected patient population (EVOLVeS Study). J Vasc Surg. 2003;38(2):207-14.

16. Siribumrungwong B, Noorit P, Wilasrusmee C, Attia J, Thakkinstian A A systematic review and meta-analysis of randomised controlled trials comparing endovenous ablation and surgical intervention in patients with varicose vein. Eur J Vasc Endovasc Surg. 2012;44(2):214-23.

17. Mendes CA, Martins AA, Fukuda JM, Parente JB, Munia MA, Fioranelli $A$, et al. Randomized trial of radiofrequency ablation versus conventional surgery for superficial venous insufficiency: if you don't tell, they won't know. Clinics (Sao Paulo). 2016;71(11):650-6.

18. Engelhorn CA, Engelhorn AL, Cassou MF, Salles-Cunha SX. Patterns of saphenous reflux in women with primary varicose veins. J Vasc Surg. 2005;41(4):645-51.

19. Konoeda H, Yamaki T, Hamahata A, Ochi M, Sakurai H. Quantification of superficial venous reflux by duplex ultrasound-role of reflux velocity in the assessment the clinical stage of chronic venous insufficiency. Ann Vasc Dis. 2014;7(4):376-82.

20. Ciostek P, Michalak J, Noszczyk W. Improvement in deep vein haemodynamics following surgery for varicose veins. Eur I Vasc Endovasc Surg. 2004;28(5):473-8

21. Yamaki T, Nozaki M, Fujiwara O, Yoshida E. Comparative evaluation of duplex-derived parameters in patients with chronic venous insufficiency: correlation with clinical manifestations. I Am Coll Surg. 2002;195(6):82230.

22. Maffei FHA, Lastoria S, Yoshida WB, Rollo HA. Doenças vasculares periféricas. $3^{\text {rd }}$ ed. Rio de Janeiro: Medsi; 2002.

23. Garrido M, Santos Ferreira C, Sales EA. Varizes de membros inferiores: Patologia. In: Maffei FHA, Lastória S, Yoshida WB, Rollo HA. Doenças vasculares periféricas. 3a. ed. Rio de Janeiro; Medsi; 2002. Volume 2. p. 1511-20

24. Silveira PRM. Estudo estrutural da veia safena magna normal e varicosa [Tese de doutorado]. São Paulo: Escola Paulista de Medicina; 1992. 